\title{
Analisis Wilayah Nodal Berdasarkan Analisis Hierarki Wilayah di Kabupaten Malang
}

\author{
Nodal Area Analysis based on Regional Hierarchical Analysis in Malang \\ Regency
}

\author{
Dewi Ranggana*, Wasrob Nasrudin \\ Jurusan Pertanian, Politeknik Pembangunan Pertanian Bogor \\ ${ }^{*}$ Korespondensi penulis, E-mail: faradeeraa@gmail.com
}

Diterima: April 2021

Disetujui terbit: Juni 2021

\begin{abstract}
The development of the Malang Regency area with the largest population in East Java needs to be considered. The existence of a regional hierarchy by assessing aspects of the population as well as the existing facilities and infrastructure in each sub-district can see the center of growth and optimize the potential of the region, especially in the agricultural sector. And infrastructure for each sub-district, determine the capital and hinterland areas, and plan regional development with an agribusiness system approach. The research method uses data collection techniques and secondary data analysis sourced from BPS (Central Bureau of Statistics) and the Ministry of Education and Culture. The results of the regional hierarchical analysis show that Singosari District occupies the highest hierarchy as the core or center of regional development, with various factors such as population, number of facilities, transportation, and historical value. The hinterland area is divided into three divisions based on the comparative analysis of the population and the number of facilities and infrastructure in each sub-district. Determination of regional development centers with this analysis, focused on each agribusiness subsystem with an emphasis on superior products of each region and creative marketing as well as optimizing regional development plans that are tailored to the region itself.

Keywords: analysis, nodal region; region hierarchy.
\end{abstract}

\begin{abstract}
ABSTRAK
Kabupaten Malang memiliki populasi penduduk yang terbesar di Jawa Timur. Oleh karena itu, pengembangan wilayahnya harus diperhatikan. Hierarki wilayah dilakukan lewat penilaian aspek jumlah penduduk serta sarana dan prasarana yang ada di masing-masing kecamatan. Hasilnya, berdasarkan jumlah penduduk serta sarana dan prasarana yang ada di masing-masing kecamatan, terlihat bahwa pusat pertumbuhan dan perlu mengoptimalkan potensi wilayahnya terutama dalam sektor pertanian. Tujuan penulisan adalah menetapkan hierarki wilayah nodal Kabupaten Malang berdasarkan data jumlah penduduk dan data jumlah sarana dan prasarana setiap kecamatan, menetapkan wilayah ibukota dan hinterland serta merencanakan pengembangan wilayah dengan pendekatan sistem agribisnis. Metode penelitian menggunakan teknik pengumpulan data dan analisis data sekunder yang bersumber dari BPS (Badan Pusat Statistik) dan Kementerian Pendidikan dan Kebudayaan. Hasil dari analisis hierarki wilayah menunjukkan bahwa Kecamatan Singosari menempati hieraki tertinggi sebagai inti atau pusat pengembangan wilayah, dengan berbagai faktor seperti penduduk, jumlah sarana, transportasi dan memiliki nilai
\end{abstract}


historis. Wilayah hinterland terbagi dalam tiga berdasarkan komparasi hasil analisis jumlah penduduk dan jumlah sarana dan prasarana yang ada di masing-masing kecamatan. Penentuan pusat pengembangan wilayah dengan analisis tersebut, difokuskan pada tiap subsistem agribisnis dengan menitikberatkan produk unggulan tiap daerah dan pemasaran kreatif serta mengoptimalkan rencana pengembangan wilayah yang disesuaikan dengan wilayah itu sendiri.

Kata kunci: analisis, nodal; hierarki wilayah,

\section{PENDAHULUAN}

Kabupaten Malang merupakan kabupaten dengan populasi terbesar di Provinsi Jawa Timur dengan jumlah populasi sebanyak 2.654.448 jiwa. Kabupaten Malang memiliki luas wilayah 334.787 ha yang menjadikan kabupaten ini menempati posisi terluas kedua di Provinsi Jawa Timur setelah Kabupaten Banyuwangi (BPS 2020). Ibu kota Kabupaten Malang terletak di Kecamatan Kepanjen yang diresmikan pada tahun 2008 berdasarkan PP No. 18 Tahun 2008. Penetapan ini memengaruhi kondisi ekologi Kecamatan Kepanjen dalam faktor seperti faktor politik, ekonomi, sosial budaya, dan daya dukung lingkungannya. Letak geografis Kecamatan Kepanjen yang strategis dapat mempercepat perkembangan wilayah. Adanya fasilitas jalan antar kecamatan, kabupaten dan provinsi juga akan mempercepat perkembangan. Perkembangan sebuah kota juga memiliki masalah yang sangat kompleks dan telah memunculkan beragam masalah sosial, salah satunya adalah kriminalitas. Banyaknya tindakan kriminalitas di Kepanjen diakibatkan oleh tingginya tingkat pengangguran, dan banyaknya masyarakat yang putus sekolah (Fariz 2019).

Kabupaten Malang memiliki kondisi topografi yang beragam dari 02000 mdpl. Hal ini dikarenakan letaknya berada di dataran rendah dan dataran tinggi hingga pegunungan. Terdapat 33 kecamatan yang tersebar pada wilayah perkotaan dan perdesaan. Setiap kecamatan di Kabupaten Malang memiliki potensi wilayah masing-masing namun belum dimanfaatkan secara optimal. Penyebabnya adalah tidak terpetakannya potensi wilayah sehingga pengembangannya terhambat.

Pengembangan wilayah merupakan upaya pemerataan yang mengacu pada perkembangan sosial ekonomi, pemeliharaan kelestarian lingkungan dan penurunan kesenjangan social (Nugroho et al. 2014). Penentuan hierarki wilayah diperlukan karena setiap wilayah memiliki potensi, sosial ekonomi, dan kondisi geografis yang berbeda-beda. Suatu wilayah dapat diukur 
perkembangannya dari ketersediaan fasilitas umum yang ada di wilayah tersebut. Metode praktis yang dapat digunakan untuk mengukur perkembangan suatu wilayah (hierarki) adalah dengan menghitung jumlah dan jenis sarana prasarana pelayanan (infrastruktur) yang ada pada suatu wilayah (Marasabessy 2016). Wilayah yang memiliki sarana dan prasarana yang lebih lengkap memiliki pertumbuhan ekonomi yang lebih baik. Pertumbuhan ekonomi jika diarahkan ke daerah-daerah yang memiliki potensi maupun fasilitas yang tinggi juga akan mempercepat terjadinya kemajuan ekonomi karena secara tidak langsung kemajuan daerah akan membuat masyarakat mencari kehidupan yang lebih layak di daerahnya (Irfanti 2019). Kebijakan pembangunan ekonomi oleh pemerintah daerah diharapkan mampu memaksimalkan potensi yang ada di daerahnya sehingga diperoleh hasil yang optimal (Alfandi 2019).

Wilayah nodal adalah suatu wilayah yang secara fungsional mempunyai ketergantungan antara daerah inti (pusat) dengan daerah belakangnya (hinterland). Tingkat ketergantungan dapat dilihat dari barang dan jasa, arus penduduk, faktor produksi, komunikasi, dan transportasi. Hubungan antara desa dan kota tidak dapat dipisahkan karena keduanya memiliki peran dan fungsinya masing-masing. Hierarki wilayah merupakan upaya untuk menciptakan pusat-pusat pengembangan wilayah yang lebih efisien. Hierarki wilayah akan menggambarkan fungsi setiap wilayah sebagai akibat dari perbedaan kualitas dan kuantitas prasarana pelayanan (Siska 2019).

Tujuan penulisan artikel ilmiah ini adalah untuk memaparkan hasil analisis hierarki wilayah berdasarkan data jumlah penduduk serta akumulasi data sarana dan prasarana setiap kecamatan di Kabupaten Malang. Hasilnya adalah penentuan wilayah nodal yakni ibu kota dan wilayah hinterland yang memiliki hubungan fisiologis antara desa dan kota, perencanaan pengembangan wilayah dengan pendekatan sistem agribisnis.

\section{METODE}

\section{Metode Penelitian}

Metode penelitian dilakukan dengan metode pengumpulan data dan metode analisis data. Data yang dikumpulkan merupakan data sekunder yang kemudian dianalisis sehingga simpulan dapat diambil. Data yang digunakan bersumber dari Badan pusat Statistik (BPS), Kementerian Pendidikan dan Kebudayaan 
(Kemendikbud), dan didukung dengan data penelitian sejenis.

\section{Data Penduduk dan Sarana} Prasarana Kabupaten Malang

Data penelitian diakses melalui internet secara daring dan dikaji pada 18 Januari sampai 19 Maret 2021. Analisis data dilakukan dengan sistem pemeringkatan dari angka tertinggi hingga angka terendah baik untuk data jumlah penduduk maupun data sarana dan prasarana. Data yang diolah merupakan data jumlah penduduk Kabupaten Malang berdasarkan data BPS tahun 2018-2020 Hasil analisis data wilayah hierarki berdasarkan jumlah penduduk tersaji pada Gambar 1 berikut.

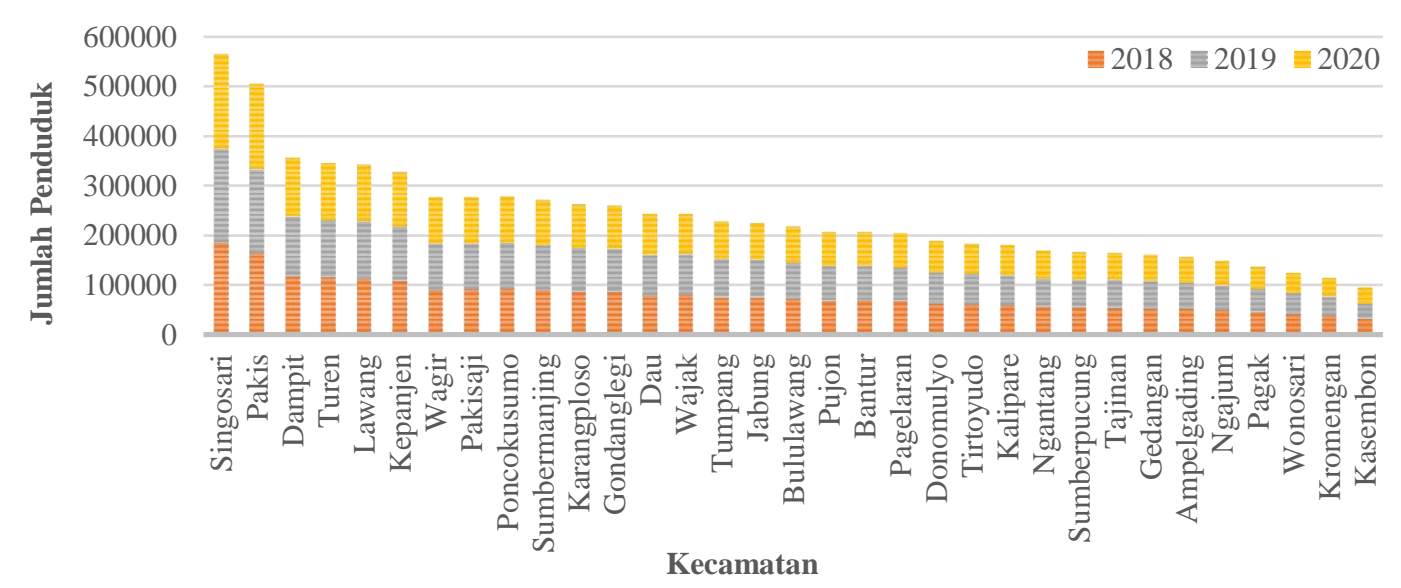

Sumber: BPS (2020)

Gambar 1 Data jumlah penduduk Kabupaten Malang tahun 2018-2020

Data sarana dan prasarana meliputi 14 kategori yakni pasar umum, toko, sekolah dasar (SD), sekolah menengah pertama (SMP), sekolah menengah atas (SMA), sekolah menengah kejuruan (SMK), KUD, non KUD, penginapan atau resort, puskesmas, rumah sakit, resto atau rumah makan, polindes dan posyandu yang ada di masing-masing wilayah 33 kecamatan di Kabupaten Malang. Data kemudian diakumulasikan untuk selanjutnya dilakukan pemeringkatan dari data tertinggi ke data terendah. Hasil analisis data tersebut tersaji pada Gambar 2 berikut. 


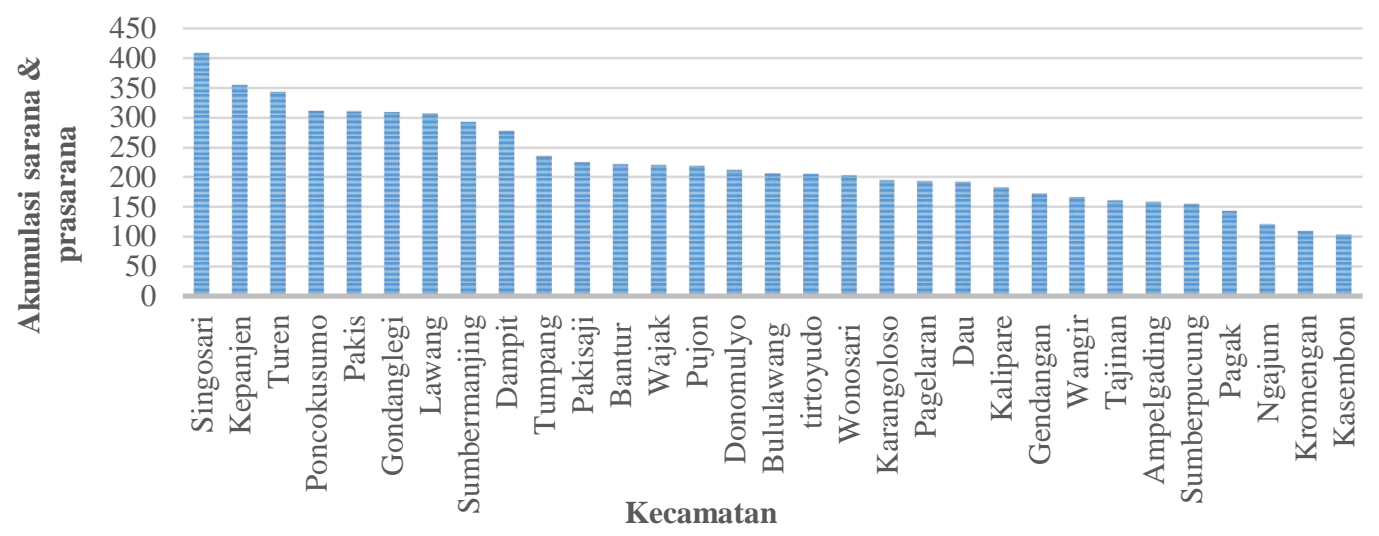

Sumber: BPS (2019) dan Kemendikbud (2019)

Gambar 2 Akumulasi data sarana dan prasana Kabupaten Malang tahun 2019

HASIL DAN PEMBAHASAN

Hierarki Wilayah Kabupaten Malang

Kecamatan

Singosari

merupakan kecamatan dengan

penduduk terbanyak yakni sebanyak 188.161 jiwa. Kecamatan Pakis menempati urutan ke 2 yakni dengan penduduk sebanyak 168.004 jiwa. Posisi ketiga teratas yakni Kecamatan Dampit dengan jumlah penduduk 118.667 jiwa. Sedangkan Kecamatan Kepanjen yang merupakan ibukota sebenarnya hanya berada di urutan ke-6 tertinggi dengan jumlah penduduk 109.109 jiwa (lihat pada Gambar 1).

Sarana dan prasarana dalam sebuah daerah merupakan alat penunjang keberhasilan suatu proses upaya yang dilakukan di dalam pelayanan publik, karena apabila kedua hal ini tidak tersedia maka semua kegiatan yang dilakukan tidak akan dapat mencapai hasil yang diharapkan sesuai dengan rencana.

Empat belas kategori yang tersaji pada Gambar 2 dipilih karena mencakup sektor ekonomi, sosial budaya, pendidikan, kesehatan dan pariwisata yang merupakan sektorsektor penting dalam pembangunan wilayah. Sarana dan prasarana juga berperan penting dalam melindungi kesehatan masyarakat dan keberlanjutan lingkungan hidup, yang dalam hal ini penting dalam menunjang perbaikan serta keberlangsungan kegiatan ekonomi, peningkatan kesejahteraan masyarakat dan pelayanan masyarakat.

Daerah yang paling baik adalah daerah yang mampu memenuhi kebutuhan masyarakatnya dengan sarana dan prasarana demi keberlangsungan hidup yang lebih 
mudah. Analisis pada Gambar 2 menunjukkan Keircamatan Singosari menempati posisi pertama dengan akumulasi data sebanyak 408 sarana dan prasarana. Jumlah data tersebut meliputi 68 SD, 29 SMP, 6 SMA, 14 SMK, 2 KUD, 76 non KUD, 5 penginapan, 2 puskesmas, 2 rumah sakit, 26 resto/rumah makan, 15 polindes dan 159 posyandu. menempati posisi kedua dengan akumulasi data sebanyak 354 sarana dan prasarana. Jumlah data tersebut meliputi meliputi 56 SD, 22 SMP, 9 SMA, 13 SMK, 1 KUD, 84 non KUD, 9 penginapan, 1 puskesmas, 3 rumah sakit, 24 Resto/rumah makan, 18 polindes dan 108 posyandu. Komparasi antara kedua data dari kecamatan dapat dilihat pada Gambar

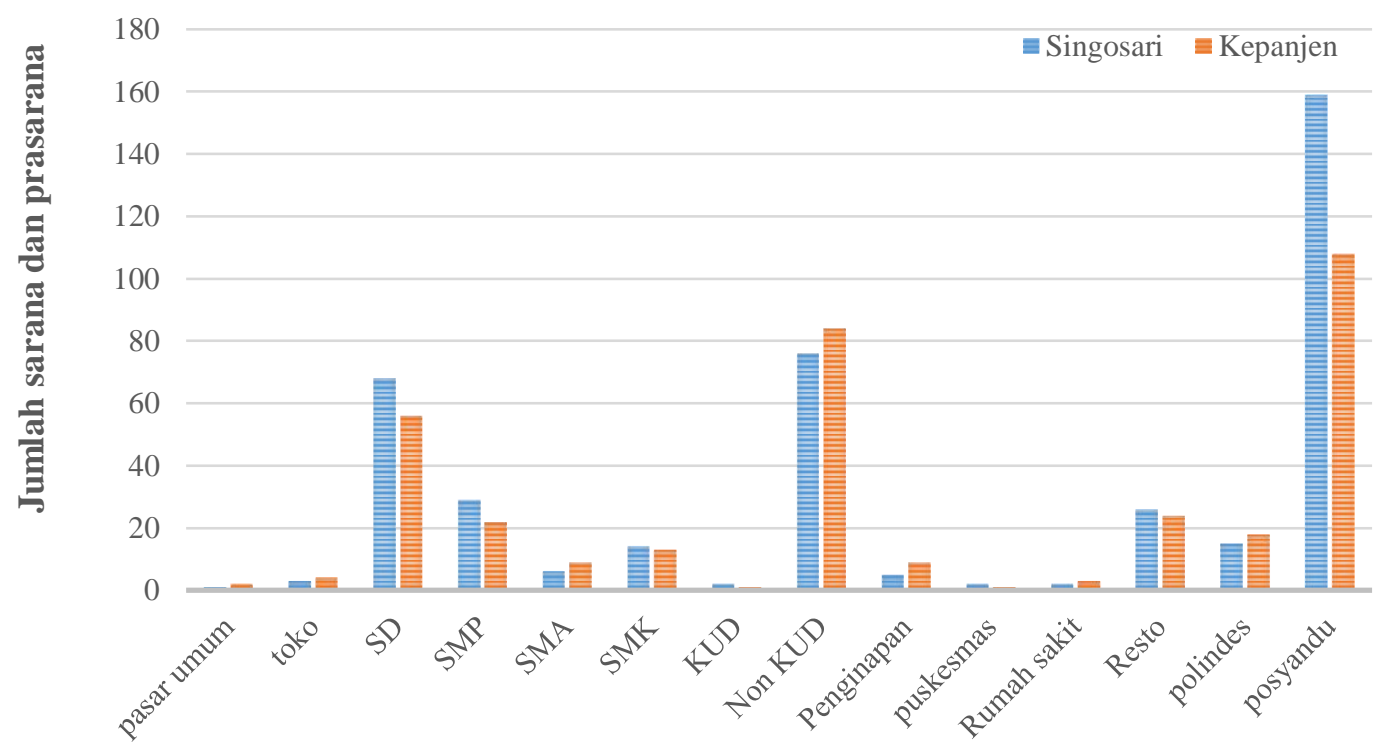

Sarana dan prasarana

Sumber: BPS (2019) dan Kemendikbud (2019)

Gambar 3 Komparasi data sarana dan prasarana Kecamatan Singosari dan Kecamatan Kepanjen tahun 2019

Wilayah Ibu Kota Kabupaten Malang berdasarkan Analisis Data Jumlah

Penduduk dan Data Saran dan Prasana

Data analisis di atas menunjukkan bahwa Kecamatan Singosari menjadi ibu kota Kabupaten Malang karena jumlah penduduk yang ada merupakan yang paling tinggi dalam kurun waktu tahun 2018 sampai dengan tahun 2020 (lihat Gambar 1). Jumlah penduduk tertinggi tersebut yakni sebanyak 185.807 jiwa pada tahun 2018, 188.161 jiwa pada tahun 2018 dan bahkan mencapai angka 190.847 jiwa pada tahun 2020. Data tersebut memiliki perbedaan cukup signifikan dibandingkan kecamatan 
lain dengan selisih antara angka 20.000 jiwa. Kecamatan Singosari memiliki luas sekitar $118,51 \mathrm{~km} 2$ atau sekitar $3,98 \%$ dari total luas wilayah Kabupaten Malang.

Secara fungsional ditinjau dari segi transportasi kecamatan ini terdapat gerbang tol yang menghubungkan Surabaya-Malang dan menjadi salah satu daerah titik macet terparah di Malang. Hal tersebut menunjukkan bahwa daerah ini merupakan daerah yang sibuk dan menjadi arus penduduk di sekitarnya. Jika ditinjau dari sisi sumber daya manusia, Kecamatan Singosari dapat dikatakan sebagai kecamatan termaju dan terpandang di Kabupaten Malang yang didukung dengan data jumlah sarana dan prasarana yang lebih banyak dan lebih lengkap dibandingkan kecamatan lain termasuk Kecamatan Kepanjen yang merupakan ibu kota Kabupaten Malang yang sebenarnya. Secara historis wilayah Kecamatan Singosari telah menjadi wilayah sentral dan menjadi pusat kegiatan masyarakat. Sejarah Singosari pada awalnya adalah sebuah kerajaan di Jawa Timur yang didirikan oleh Ken Arok pada tahun 1222 M. Adanya ketergantungan wilayah lain pada Kecamatan Singosari menegaskan bahwa wilayah ini merupakan wilayah ibu kota, meskipun pada nyatanya Kecamatan Kepanjen yang menjadi ibu kota.

\section{Wilayah Hinterland Kabupaten Malang berdasarkan Analisis Data Jumlah Penduduk dan Data Saran dan Prasana}

Secara umum, wilayah di setiap kecamatan di Kabupaten Malang memiliki keunggulan produk dan komoditas unggulannya masingmasing. Klasifikasi hierarki wilayah hinterland berdasarkan analisis data jumlah penduduk dan data jumlah sarana dan prasarana ialah sebagai berikut:

1) Wilayah hinterland I

Wilayah hinterland I meliputi wilayah 10 wilayah pertama dengan akumulasi data jumlah penduduk dan sarana prasarana yakni Kecamatan Kepanjen, Kecamatan Turen, Kecamatan Poncokusumo, Kecamatan lawang, Kecamatan Pakis, Kecamatan Dampit, Kecamatan Pakisaji, Kecamatan Sumbermanji, Kecamatan Gondanglegi dan Kecamatan Tumpang.

2) Wilayah hinterland II

Wilayah hinterland II meliputi wilayah 10 kedua dari hinterland I dengan akumulasi data jumlah penduduk dan sarana prasarana yakni Kecamatan Wajak, 
Kecamatan Bantur, Kecamatan

Pujon, Kecamatan Donomulyo,

Kecamatan

Bululawang,

Kecamatan Tirtoyudo, Kecamatan

Karang Ploso, Kecamatan

Sumbermanji, Kecamatan Dau dan

Kecamatan Pagelaran.

3) Wilayah hinterland III

Wilayah hinterland III meliputi wilayah terakhir yang tersisa dengan dari akumulasi data jumlah penduduk dan sarana prasarana yakni Kecamatan Kalipare, Kecamatan Wangir, Kecamatan Gedangan, Kecamatan

Ampelgading, Kecamatan Tajinan, Kecamatan

Sumberpucung,

Kecamatan Ngajum, Kecamatan Pasak, Kecamatan Kromegan, Kecamatan Ngantam, Kecamatan wonosari, dan Kecamatan Kasembon.

\section{Hubungan Fungsional antara Desa dan Kota di Kabupaten}

Wilayah nodal berarti adanya hubungan inti dengan wilayah di belakangnya atau hubungan antara kota dan desa disekitarnya yang mana dalam hal ini wilayah inti ialah Kecamatan Singosari. Wilayah hinterland I merupakan wilayahwilayah yang menjadi wilayah homogen pada komoditas tertentu yakni untuk Kecamatan
Poncokusumo, Kecamatan Pujon, dan Kecamatan Tumpang merupakan wilayah homogen komoditas apel yang merupakan buah unggulan di Malang. Sedangkan untuk daerah Kecamatan Kepanjen dan Kecamatan Dampit merupakan wilayah homogen padi/beras yang merupakan makanan pokok masyarakat.

Terpusatnya kegiatan di ibukota berdasarkan analisis yakni Kecamatan Singosari mendukung kegiatan masyrakat dengan lengkapnya sarana dan prasarana yang ada. Mudahnya akses jalan dan transportasi membuat kegiatan perekonomian bergerak dengan baik (Prasetiyo et al. 2014)

\section{Perencanaan Pengembangan \\ Wilayah}

Rencana pengembangan wilayah nodal Kabupaten Malang berdasarkan analisis pendekatan agribisnis di wilayah ibu kota dan wilayah hinterlandnya ialah sebagai berikut: Subsistem agro-input optimalisasi dana pemerintah atau dana desa dengan pengadaan input pertanian yang kemudian dimanfaatkan oleh masing-masing petani daerah, pengadaan dan penyaluran sarana dan prasarana produksi.

1) Subsitem agro-production dengan melakukan optimalisasi usaha tani 
melalui menerapakan sistem OVOP

(One Village One Product) sehingga biaya input baik dalam pengadaan alat mesin dan berbagai hal-hal yang diperlukan dalam budidaya bisa lebih murah karena biaya transportasi yang digunakan juga lebih murah.

2) Subsistem agro-industry dan agroprocessing dengan melakukan pengolahan produk berdasarkan unggulan daerah di setiap wilayah hinterland. Langkah selanjutnya adalah pabrik bisa didirikan di daerah ibukota atau yang tidak jauh dari ibukota agar distribusi produk lebih cepat. Inovasi produk dengan peningkatan variasi hasil pengolahan untuk menciptakan nilai tambah dan nilai jual daripada produk segarnya. Sebagai contoh ialah berbagai produk olahan buah apel dan jambu (Susanti dan Afrilia 2016). .

3) Subsistem

agro-marketing dilakukan dengan cara membuat situs khusus daerah agar branding produk yang dilakukan terpusat, pemasaran kreatif melalui media sosial online marketplace, dengan tagar dan tagline agar produk bisa viral. Contoh tagar yang dapat digunakan ialah \#produkkabmalang, \#theheartofeastjava dan lain sebagainya.

4) Subsistem agro-supporting perlu adanya regulasi dan kebijakan pemerintah, karena tidak dapat dipungkiri kebijakan pemerintah benar-benar berpengaruh terhdap usaha pertanian. Penyuluhan kepada petani dan masyarakat diharapkan mampu meningkatkan pemahaman dan menghasilkan perubahan perilaku. Penyuluhan tidak hanya berorientasi pada to do list namun juga dalam perubahan pola pikir masyarakat itu sendiri (Putra et al. 2013).

\section{SIMPULAN DAN SARAN}

Berdasarkan hasil analisis di Kecamatan Singosari ditetapkan sebagai wilayah lbukota atau inti, meskipun pada kenyataanya Kecamatan Kepanjen merupakan ibu kota sebernarnya. Faktor yang memengaruhi antara lain Kecamatan Singosari memiliki populasi penduduk tertinggi, jumlah sarana prasarana yang lebih lengkap, pusat transportasi dan memiliki nilai historis sebagai pusat pertumbuhan sejak masa Kerajaan Singosari. Wilayah hinterland dibagi menjadi tiga berdasarkan hasil analisis jumlah penduduk dan jumlah sarana dan prasarana yang ada di masing-masing kecamatan. 
Hubungan antara desa dan kota di Kabupaten Malang cukup jelas misalnya dalam perpindahan arus penduduk, persebaran komoditas tertentu, dan sarana transportasi. Rencana pengembangan wilayah Kabupaten Malang dilakukan melalui pendekatan subsistem agribisnis dengan menerapkan kebijakan pada setiap subsistem, produk unggulan tiap daerah dan pemasaran kreatif.

\section{Penerapan perencanaan} dengan pendekatan sistem agribisnis diharapkan dapat memajukan dan membangun daerah baik wilayah ibu kota maupun wilayah hinterland, maka perlu dilakukan pengkajian ulang terkait penetapan wilayah ibu kota tersebut dengan memperhatikan aspek-aspek pengembangan wilayah terutama pada sistem agribisnisnya.

\section{DAFTAR PUSTAKA}

[BPS] Badan Pusat Statistik. 2019a. Kecamatan Singosari Dalam Angka 2019. Kabupaten Malang: BPS Kabupaten Malang

$2019 b$. Badan Pusat Statistik. 2019. Kabupaten Malang Dalam Angka 2019. Kabupaten Malang: BPS Kabupaten Malang

2020a.

2020. Kabupaten Malang Dalam Angka 2020. Kabupaten Malang: BPS Kabupaten Malang
$2020 b$.

Penduduk, Luas Wilayah dan Kepadatan Penduduk Menurut Kecamatan, Tahun 2015-2020. Kabupaten Malang: BPS Kabupaten Malang

[Kemendikbud] Kementrian Pendidikan dan Kebudayaan. 2019. Jumlah Data Satuan Pendidikan (Sekolah) Per Kabupaten/Kota: Kab. Malang. Tangerang selatan: KEMENDIKBUD

Alfandi K. 2019. Analisis Potensi Sektor Unggulan sub sektor Pertanian di Kabupaten Malang dan Provinsi Jawa Timur 20122016 [Skripsi]. Malang: Universitas Muhammadiyah Malang

Fariz HA. 2019. Kepanjen: Pekembangan Ekologi Kota Kecamatan di Kabupaten Malang 1981-2016 [Skripsi]. Malang: Universitas Negeri Malang.

Irfanti PE. 2019. Analisis Penentuan Pusat Pertumbuhan dan Wilayah Hinterland dalam Pengembangan Provinsi Jawa Timur [Skripsi]. Jember: Universitas Jember.

Marasabessy F. 2016. Hirarki Wilayah Kota Ternate Pasca Pengembangan Kawasan Waterfront City. Jurnal Wilayah Dan Lingkungan. Vol 4(3): 213224.

Nugroho I, Dahuri R. 2004. Pembangunan Wilayah: Perspektif Ekonomi, Sosial dan Lingkungan. Jakarta: LP3ES.

Prasetiyo $F$, Hidayat $R$, Sulistio $H$, Arifin MZ. 2014. Kajian Manajemen Lalu Lintas Sekitar Kawasan Pasar Singosari Kabupaten Malang. Jurnal Mahasiswa Jurusan Teknik Sipil. Vol 1(2): 749-755.

Putra CK, Pratiwi PN, Suwondo. 2013. Pengelolaan Alokasi Dana Desa dalam

Pemberdayaan 
Masyarakat Desa (Studi Pada Desa Wonorejo Kecamatan Singosari Kabupaten Malang). Jurnal Administrasi Publik (JAP): Vol. 1(6): 1203-1212.

Siska, D. 2019. Hirarki Wilayah Berdasarkan Fasilitas Pelayanan di Kabupaten Banjar. Jurnal Kebijakan Pembangunan. Vol 14(2): 125-131.

\begin{tabular}{lrr}
$\begin{array}{c}\text { Susanti S, Afrila A. } \\
\text { Pemberdayaan }\end{array}$ & 2016. \\
Lahan \\
Pekarangan untuk & Budidaya \\
Tanaman & Organik r di \\
Prodosumbul & Desa Klampok \\
Kecamatan & \multicolumn{4}{c}{ Singosari } \\
Kabupaten Malang. Jurnal Akses \\
Pengabdian Indonesia. Vol 1(1): \\
18-33
\end{tabular}

Susanti S, Afrila A. 2016. Pemberdayaan Tanaman Organik di Prodosumbul Desa Klampok Kabupaten Malang. Jurnal Akses 18-33 